\section{ISOLATION \\ AND \\ BACTERIA FROM SIDOARJO SHRIMP PASTE AS PROTEASE SOURCE TO EXTRACT THE COLLAGEN FROM MILKFISH SCALES (CHANOS CHANOS)}

A Evi Susantia,b*, Suhartia,b, Roswanira Abdul Wahabc,d, Naharotul Chusniyaha, Shindy Tirta Ayu Paramitha ${ }^{a}$

aDepartment of Biotechnology, Faculty of Mathematics and Natural Sciences, Universitas Negeri Malang, 65145, Indonesia bDepartment of Chemistry, Faculty of Mathematics and Natural Sciences, Universitas Negeri Malang, 65145, Indonesia cDepartment of Chemistry, Faculty of Science, Universiti Teknologi Malaysia, 81310, UTM Johor Bahru, Johor, Malaysia dEnzyme Technology and Green Synthesis Group, Faculty of Science, Universiti Teknologi Malaysia, 81310, UTM Johor Bahru, Johor, Malaysia
Article history

Received

5 September 2021

Received in revised form

10 November 2021

Accepted

14 November 2021

Published Online

20 December 2021

${ }^{*}$ Corresponding author
evi.susanti.fmipa@um.ac.id

\section{Graphical abstract}

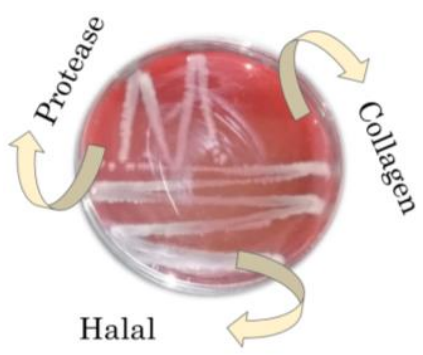

\begin{abstract}
This research aimed to isolate protease-producing bacteria from Sidoarjo shrimp paste for extracting collagen from milkfish scales. This study began with isolation, followed by screening and purification of protease-producing bacterial isolates. Further confirmation of the isolates' proteolytic indices and the crude protease production, the enzymes' efficacy in extracting collagen from milkfish scales were tested, followed by pathogenicity and identification using 16S rRNA molecular technique. The study has successfully isolated 15 proteolytic bacterial isolates using skimmed milk agar, but only isolates of TR-10, TR-4.1.1, and TR-15.1 exhibited prospective proteolytic activity based on their corresponding proteolytic indices of $2.96 \pm 0.06,3.10 \pm 0.10$, and $3.71 \pm 0.48$. Although the proteolytic activity of isolates TR-10 (0.22 $\pm 0.05 \mathrm{U} / \mathrm{mL})$ and TR-15.1 (1.07 $\pm 0.14 \mathrm{U} / \mathrm{mL})$ was high in a salt medium using peptone as the nitrogen source, only the former showed satisfactory activity to extract soluble collagen from milkfish scales. Based on the 16SrRNA, the TR-10 isolate was identified as Bacillus megaterium. The non-pathogenicity of the TR-10 bacterium signified its promising role as a protease source for the halal collagen extraction from milkfish scales.
\end{abstract}

Keywords: Collagen, Fish, Halal, Protease. Isolation

\begin{abstract}
Abstrak
Penyelidikan ini bertujuan untuk mengasingkan bakteria penghasil protease dari pes udang Sidoarjo untuk mengekstrak kolagen dari sisik bandeng. Kajian ini dimulakan dengan pengasingan, diikuti dengan penyaringan dan pemurnian isolat bakteria penghasil protease. Pengesahan lebih lanjut mengenai indeks proteolitik isolat dan pengeluaran protease mentah, keberkesanan enzim dalam mengekstrak kolagen dari sisik bandeng diuji, diikuti oleh patogenik dan penilaian identifikasi molekul 165 rRNA. Kajian berjaya mengasingkan 15 isolat bakteria proteolitik menggunakan media agar susu skim, tetapi hanya isolat TR-10, TR-4.1.1, dan TR-15.1 menunjukkan prospek aktiviti proteolitik berdasarkan indeks proteolitik masing-masing $2.96 \pm 0.06,3.10 \pm 0.10$, dan $3.71 \pm 0.48$. Walaupun aktiviti
\end{abstract}


proteolitik isolat TR-10 $(0.22 \pm 0.05 \mathrm{U} / \mathrm{mL})$ dan TR-15.1 (1.07 $\pm 0.14 \mathrm{U} / \mathrm{mL})$ tinggi dalam medium garam menggunakan peptone sebagai sumber nitrogen, hanya yang menunjukkan aktiviti yang memuaskan untuk mengekstrak kolagen larut dari sisik ikan Bandeng. Berdasarkan 165 rRNA, isolat TR10 teridentifikasi sebagai Bacillus megaterium. Ketidak-patogenan bakteria TR-10 menandakan peranannya yang menjanjikan suatu sumber protease untuk pengekstrakan kolagen halal dari sisik ikan bandeng.

Kata kunci: Kolagen, Ikan, Halal, Protease. Pengasingan

(C) 2022 Penerbit UTM Press. All rights reserved

\subsection{INTRODUCTION}

The increasing awareness among consumers on the benefits and usefulness of collagen has led to its steady rise in demand. This has to do with the ability of collagen as a water-absorbent, gelling agent, as a former, and emulsion stabilizer in the food industry. Collagen has multiple roles in the health and pharmaceutical industries, such as drug carriers and protein substitutes for human skin, blood vessels, and ligaments. Other bioactive functions of collagen include antimicrobial, antioxidant, and antihypertensive agents [1].

Collagen is extracted from various animal connective tissues, such as the inner skin layer (dermis), tendon, bone, cartilage, teeth, animal skin and bone tissues [3], scales, and fish bones. Literature has shown that collagen yields from the scales, skins, and fins of Cyprinus carpio and Hypophthalmichthys molitrix could reach as much as 29,28 , and $21 \%$, respectively $[4,5,6,7]$. Fish collagen is a more popular alternative source of halal collagen and healthier than pork and beef collagen. Although researchers have widely studied numerous marine fish, including the brown-banded bamboo shark, bigeye sniper, threadfin beam, sea bass, and grass carp as a collagen source [8], the freshwater fish has been largely overlooked. The Milky fish (Chanos chanos) could be an attractive collagen source, considering its high availability in the Sidoarjo province in East Java. About 16.0 thousand tons of milkfish were produced in 2009, which rose to 23.3 thousand and 33.8 thousand tons in 2011 and 2015, respectively [9]. Milkfish waste, especially the scales, has a high protein content of between $41-84 \%$ in the form of collagen and ichtylepidin [2]. The lipid content of the fish is the lowest, which simplifies the delipidating process [7]. Furthermore, the relatively small size and large surface area of fish scales avert any pretreatment at the preparation stage.

Collagen extraction is typically performed by chemical (acid or base) and enzymatic processes. However, the former is the preferred technique due to its simplicity which involves random hydrolysis of peptide bonds to yield polypeptides of various sizes. The downside of the chemical technique is the low product yield and production of corrosive waste, which could have adverse effects on the immediate environment [3]. On the other hand, the enzymatic method is more sustainable given the selectivity of enzymes, resulting in higher yield and purity $[1 ; 3]$. The protease-assisted extraction of collagen from the lungs of soft-shell tortoises Pelodiscus sinensis by Song and Wei afforded a high collagen yield of $60 \%$ compared to the acid (50\%) and base methods (10 $\%$ [10]. The protease breaks the connective tissue peptide bonds to yield $\pm 300 \mathrm{kDa}$ collagen of the triple helix protein segment [3]. However, there is an issue with using proteases for this purpose. This is because porcine pepsin is the enzyme of choice for the process, which renders the collagen product non-halal for Muslim consumption. In this milieu, an alternative halal protease, preferably of microbial origin, must be found.

The use of bacteria as a source of protease is highly feasible, given their high growth rates and the limited space for their cultivation. The easy manipulation of bacterial genetics to create new enzymes with altered properties for different applications is highly desirable [11]. To date, different kinds of proteolytic bacteria have been successfully isolated from traditional fermented soy-based foods, i.e., soybean. The high protein content in soybeans makes them good substrates for cultivating proteolytic bacteria. Chantawannakul et al. reported the isolation of a proteolytic bacterium, Bacillus subtillis, from thua nao (Thai fermented soybean food) [12]. In contrast, Cho et al. isolated the protease-producing B. amyloliquefaciens from meju (Korean fermented soybean food) [13]. Susanti et al. successfully isolated eight potential proteolytic bacteria from Indonesian fermented soybean called tauco [14].

In this study, the traditional fermented shrimp paste, also called terasi, was used as a source of protease-producing bacteria, capable of extracting collagen from discarded milkfish scales. The uniquely savory-tasting and glutamic acid-rich Cirebon, Tuban, and Malang shrimp pastes were previously documented to contain 15, 17 , and $25 \%$ proteolytic bacteria, respectively, from the total microorganisms, partaking in the fermentation process [15]. However, the Sidoarjo shrimp paste as a source of bacterial proteases remains unreported. This research aimed to 
isolate protease-producing bacteria from Sidoarjo shrimp paste, and the enzyme is used to extract collagen from milkfish scales. The study first isolated and screened for protease-producing bacteria. Then, the isolates' proteolytic indices were confirmed, and the crude protease was prepared. The enzymes were tested for their efficacy in extracting collagen from milkfish scales, followed by a pathogenicity test to ensure their safety for assisting in food processing. Lastly, the study performed $16 \mathrm{~S}$ rRNA molecular identification to identify the protease-producing bacterium.

\subsection{METHODOLOGY}

\subsection{Chemicals and Reagents}

Sidoarjo shrimp paste was purchased from Dukuh Sari Village, Jabon Sub-District, Sidoarjo Regency. The selective medium for growing proteolytic bacteria compose of bactoagar (1.5\%); skim milk (5\%); $\mathrm{NaCl}$ $(0,05 \%)$. Analytical grade chemicals, glucose, casein, peptone, $\mathrm{MgSO}_{4} .7 \mathrm{H}_{2} \mathrm{O}, \mathrm{KH}_{2} \mathrm{PO}_{4}, \mathrm{Na}_{2} \mathrm{CO}_{3}, \mathrm{FeSO}_{4} .7 \mathrm{H}_{2} \mathrm{O}$, bovine serum albumin, Folin-Ciocalteu reagent, TCA (Trichloroacetic acid), tyrosine standard, and phosphate buffer were purchased from SigmaAldrich, USA. Blood agar was procured from the Microbiology Laboratorium of Medical School, Universitas Brawijaya.

2.2 Isolation and Screening of Proteolytic Bacteria from the Bacterial Consortium of Sidoarjo Shrimp Paste

Twenty-five grams of shrimp paste was aseptically ground with a mortar and pestle, and was dissolved in $225 \mathrm{~mL}$ of $0.85 \%(\mathrm{w} / \mathrm{v})$ sterile physiological saline solution and homogenized to give the stock solution. The $\mathrm{pH}$ of the sample stock was read using a universal indicator paper, and protein concentrations of test samples were estimated using the Lowry method. The sample stock was serially diluted to prepare the calibration series for protein estimation. A $100 \mu \mathrm{L}$ aliquot of each dilution was withdrawn and evenly spread over the skim milk agar (SMA) using a sterile spreading stick and quadrant streak technique. This was followed by incubation at room temperature for 3 days, and the bacterial growth was confirmed by Gram staining. Proteolytic activity of bacterial colonies growing on the SMA was confirmed by observing clear zones around each colony. Each isolate's proteolytic index (IP) was measured by taking the diameter ratio of a clear zone versus the colony diameter [11]. Only isolates with IP values $>2.8$ were further purified and tested further. The bacterial isolate with the highest IP score represents the greatest proteolytic activity. The enzyme was expected to extract collagen from milkfish scales efficaciously.

\subsection{Production of the Crude Extract of Protease}

Production of crude proteases was prepared according to the method of Alnahdi [11]. Briefly, pure culture was inoculated into a $50 \mathrm{~mL}$ production medium containing ( $\mathrm{g} / \mathrm{L})$ of glucose, 5.0; peptone, 7.5; $\mathrm{MgSO}_{4} .7 \mathrm{H}_{2} \mathrm{O}$, 5.0; $\mathrm{KH}_{2} \mathrm{PO}_{4}, 5.0$; and $\mathrm{FeSO}_{4} .7 \mathrm{H}_{2} \mathrm{O}$, $0.1, \mathrm{pH}$ 7.0. The mixture was incubated at $100 \mathrm{rpm}, 37$ ${ }^{\circ} \mathrm{C}$ for 72 hours, and the enzymes were harvested by centrifugation $(3,000 \mathrm{rpm}$ for 30 minutes). The supernatant was assessed for protease activity and protein concentration using the Lowry method.

\subsection{Determination of Protein Concentration by Lowry Method}

A $0.5 \mathrm{~mL}$ of sample and $0.5 \mathrm{~mL}$ of each standard protein solution containing 0 (blank), 20, 40, 60, 80, $100 \mu \mathrm{g}$ bovine serum albumin was added to a $2.5 \mathrm{~mL}$ of $\mathrm{CuSO}_{4}$ solution and vortexed for 10 seconds to homogenize. The mixture was incubated at room temperature for 10 minutes before adding the 0.25 $\mathrm{mL}$ of the Folin-Ciocalteu reagent $(1 \mathrm{~N})$. The mixture was further incubated at room temperature for exactly 20 minutes, and the absorbance was read at $750 \mathrm{~nm}$ on a UV-visible (Spectrophotometer B-ONE, Vis 50 DA) [16].

\subsection{Assay of Protease Activity}

The protease activity of the crude enzymes was carried according to the method of Alnahdi [11]. Briefly, $0.2 \mathrm{ml}$ of the crude enzyme extract was transferred into a test tube containing $0.5 \mathrm{~mL}$ of $1 \%$ casein $(\mathrm{w} / \mathrm{v})$ dissolved in $50 \mathrm{mM}$ of phosphate buffer $(\mathrm{pH} 7)$ and incubated at $40{ }^{\circ} \mathrm{C}$ for 20 minutes. The reaction was halted by adding $10 \%$ TCA solution 11 $\mathrm{mL})$. The mixture was centrifuged $(10,000 \mathrm{rpm})$ at room temperature for 10 minutes before the addition of $\mathrm{Na}_{2} \mathrm{CO}_{3}$ solution $(2,5 \mathrm{~mL}, 0.4 \mathrm{M})$ and $1 \mathrm{~mL}$ of FolinCiocalteu reagent into the supernatant $(2.5 \mathrm{~mL})$. The mixture was incubated at room temperature for 30 min, and the absorbance read $660 \mathrm{~nm}$. The negative control reaction tubes (without enzyme) were prepared in the same manner, except TCA was added before the substrate. A unit of protease enzyme $(\mathrm{U} / \mathrm{mL})$ activity was expressed as the microgram of tyrosine produced per milliliter of enzyme solution per every minute under assay conditions. Tyrosine levels were determined by interpolation of the standard tyrosine regression curve. The tyrosine standard curve was read using a mean total of $2 \mathrm{~mL}$ of a standard solution containing 0 (blank), 10, 30, 50, 70, 90, and $110 \mu \mathrm{g} / \mathrm{mL}$ tyrosine, were added to a $5 \mathrm{~mL}$ of $0.5 \mathrm{M} \mathrm{Na}_{2} \mathrm{CO}_{3}$ solution and $1 \mathrm{~mL}$ of Folin-Ciocalteu reagent. The mixtures were vortexed and incubated at $37^{\circ} \mathrm{C}$ for 30 minutes. The absorbance of the formed blue solution was taken a $660 \mathrm{~nm}$. Protease activity was estimated according to Equation 1 [17]. 
Enzyme activity $(\mathrm{U} / \mathrm{mL})=(\mathrm{C} \times \mathrm{Ves}) /(\dagger \times \vee e)$ (Equation

1)

C = tyrosine concentration $(\mu \mathrm{g} / \mathrm{mL})$

Ves $\quad=$ total volume $(\mathrm{mL})$

$\dagger \quad=$ enzyme-substrate incubation time minutes)

Ve $\quad=$ volume of enzyme $(\mathrm{mL})$

\subsection{Morphological Screening and Biochemical Tests}

Morphological inspection and characterization of the selected bacterial isolates were done using a light microscope (Olympus CX21LEDFS1) and by Gram-straining [18].

\subsection{Protease-assisted Extraction of Collagen from Milkfish Scales}

In this study, the ability of the crude bacterial proteases to extract collagen from milkfish scales was based qualitatively on the increase in protein concentration of the reaction mixture after the enzymatic treatment. Briefly, mixture A comprising $2 \mathrm{~g}$ of fish scales, was incubated in $5 \mathrm{~mL}$ of the crude protease; mixture $\mathrm{B}$ comprised $5 \mathrm{~mL}$ of the crude protease, and mixture $C$ contained $2 \mathrm{~g}$ of fish scales incubated in $5 \mathrm{~mL}$ of distilled water (negative control). After 72 hours of incubation at room temperature, all three mixtures were centrifuged (5000 rpm, 10 minutes), and the supernatants were measured for protein content using the Lowry method [6]. The above experiment was triplicated, and the results are presented as mean \pm standard deviation.

The protein increase was observed by taking the difference in protein content in the enzymatic mixture (the crude extract of protease with milky fish scales $=$ A) minus the protein content in the control mixture (crude extract of protease $=\mathrm{B}$ and the mixture of distilled water and milky fish scales $=C$ ). In principle, the peptide bonds in connective tissue (fish scales) are hydrolyzed by proteases into short polypeptides in the form of soluble collagen, identified as the increase in protein concentration in the reacting mixture.

\subsection{Pathogenesis Assay}

The pathogenesis test on the bacterial isolates was carried out according to a modified method by Estifanos [19], using a hemolytic test on blood agar.

\subsection{Genomic DNA Extraction, Amplification,} Sequencing, and Analysis of 165 rDNA Gene of the Bacterial Isolate

Following the manufacturer's protocol, DNA purification Kit (Promega, USA) was used by this study to extract the genomic DNA from the bacterial isolates. The 16S rDNA gene of the isolate was amplified using polymerase chain reaction (PCR). The amplification reaction mixture $(50 \mu \mathrm{L})$ comprised $5 \mu \mathrm{L}$ template DNA (approximately $10 \mathrm{ng}$ of DNA), $5 \mu \mathrm{L}$ of forward $(\mathrm{fD})=$ 5' $^{\prime}$-AGAGTTTGATCCTGGCTCAG-3') and reverse $\left(\mathrm{rP} 1=5^{\prime}-\mathrm{CTACGGCTACCTTGTTACGA-3^{ \prime } )}\right.$ primers $(20 \mathrm{pmol} / \mu \mathrm{L}), 24 \mu \mathrm{L}$ of Fermentas PCR MasterMix (200 $\mu \mathrm{M}$ dNTPs; $2 \mathrm{mM} \mathrm{MgCl}$; $1.25 \mathrm{U}$ Taq polymerase), and nuclease-free water was added to make up the final volume. The late exponential phase culture was used to prepare the chromosomal DNA using the Wizard Genomic DNA Purification Kit (Promega, USA). The PCR product was electrophoresed on agarose gel $(1 \%)$ and purified using the QIAquick PCR purification kit (Qiagen, USA). The gene was sequenced at First Base Malaysia.

\subsection{Phylogenetic Analysis of 16S rDNA Gene}

The sequence was analyzed through the BLAST (Basic Local Alignment Search Tools) program at the National Center for Biotechnology Information (NCBI). The MEGA6 software was employed to construct the phylogenetic tree using the neighborjoining method, as described by Tamura and Nei [20]. The study performed a Maximum Composite Likelihood analysis to calculate the tree based on the least number of evolutionary steps, using the five hundred bootstrap replications.

\subsection{RESULTS AND DISCUSSION}

3.1 Analysis of the Sidoarjo Shrimp Paste and Isolation and Selection of Proteolytic Bacterial

The protein concentration in the stock solution of Sidoarjo shrimp paste was $76.22 \mathrm{mg} / \mathrm{mL}$, with a $\mathrm{pH}$ of 7.0 by a single measurement. Similarly, the Tuban and Samarinda shrimp pastes, alongside the Semarang shrimp paste, were $\mathrm{pH}=7.48$ [21], Tuban shrimp paste has a $\mathrm{pH}=6.0$ [15], and Samarinda shrimp paste has $\mathrm{a} \mathrm{pH}=8.5$ [22]. This study suggests that different proteolytic bacteria could be found in Sidoarjo shrimp paste. In the beginning, this study successfully isolated a total of 15 pure bacterial isolates from the Sidoarjo Shrimp paste, all of which revealed notable differences in colony morphology. Then, the purity of each isolate was confirmed by Gram staining. In unconfirmed pure bacterial isolates, further purification was carried out. It is pertinent to indicate here that several colonies such as isolates TR-4, TR-9, TR-12, and the two-isolates TR-15 make up 19 pure isolates. The study found that the proteolytic indices of the Sidoarjo shrimp paste-isolated bacteria were sufficiently diverse, with values between 1.05 to 3.32 . Of the 19 isolates, 16 isolates exhibited proteolytic indices below 2.8 (Table 1). This indicated their poor protease-producing capability, hence unsuitable for the subsequent collagen extraction process. In light of this, the study did not pursue further characterization of these 16 bacterial isolates.

It is pertinent to indicate here that the proteolytic index used in this study is a valuable parameter derived from the difference in diameter of the clear 
zone surrounding the proteolytic bacterial isolate in relevance to the diameter of the colony. A greater proteolytic index indicates the isolate's higher extracellular protease activity, wherein a proteolytic index $\geq 3$ denotes a promising source of extracellular proteases [23]. Therefore, this study only selected three isolates, TR-4.1, TR-10, and TR-15.1, for further inspection as they exhibited the highest proteolytic indices of $2.96 \pm 0.06,3.10 \pm 0.10$, and $3.41 \pm 0.48$ respectively.

The study found that isolates TR-4.1 and RT-15.1 were Gram-negative with spherical-shaped colonies. In contrast, the TR-10 isolate was Gram-positive, although the resulting Gram's color was not a clear purple. It is likely due to insufficient destaining of the safranin dye during Gram staining. However, their microscopic characteristic and their proteolytic index values were distinct. Inspection under the light microscope revealed the TR-4.1 isolate to be singlecelled Bacilli, while the TR-10 and TR-15.1 isolates were chain- and long-chain-Bacilli. Table 2 summarizes the results of this study. Interestingly, this study isolated a markedly different species of proteolytic bacteria from the Sidoarjo shrimp paste compared to the reported bacterial isolates from Malang, Tuban, and Cirebon shrimp pastes [15].

Table 1 Proteolytic Index Value of Bacteria Isolates from Sidoarjo Shrimp Paste

\begin{tabular}{llll}
\hline Isolate & Proteolytic Index & Isolate & Proteolytic Index \\
\hline & & TR-9.1 & 1.73 \\
TR-1 & 2.21 & TR-9.2 & 2.00 \\
TR-2 & 1.96 & TR-10 & 3.00 \\
TR-3 & 2.83 & TR-11 & 2.00 \\
TR-4.1 & 3.32 & TR-12.1 & 1.64 \\
TR-4.2 & 1.05 & TR-12.2 & 1.60 \\
TR-5 & 1.86 & TR-13 & 2.31 \\
TR-6 & 2.10 & TR-14 & 1.71 \\
TR-7 & 2.48 & TR-15.1 & 2.90 \\
TR-8 & 1.77 & TR-15.2 & 2.01
\end{tabular}

Table 2 Characteristics of Potential Proteolytic Bacteria Isolates from Sidoarjo Shrimp Paste

\begin{tabular}{|c|c|c|c|c|}
\hline Isolate & Colony & $\begin{array}{l}\text { Proteolytic } \\
\text { index } \\
\text { value }\end{array}$ & $\begin{array}{c}\text { Purification } \\
\text { Result }\end{array}$ & $\begin{array}{l}\text { Pure isolate } \\
\text { character } \\
\text { based on } \\
\text { gram } \\
\text { staining }\end{array}$ \\
\hline TR-4.1 & & $2.96 \pm 0.06$ & & $\begin{array}{l}\text { Single } \\
\text { bacili, } \\
\text { Gram- } \\
\text { negative } \\
\text { bacteria }\end{array}$ \\
\hline TR-10 & & $3.10 \pm 0.10$ & & $\begin{array}{l}\text { Chain } \\
\text { Bacili, } \\
\text { Gram-positif } \\
\text { bacteria }\end{array}$ \\
\hline
\end{tabular}

\begin{tabular}{|c|c|c|c|c|}
\hline Isolate & Colony & $\begin{array}{l}\text { Proteolytic } \\
\text { index } \\
\text { value }\end{array}$ & $\begin{array}{c}\text { Purification } \\
\text { Result }\end{array}$ & $\begin{array}{l}\text { Pure isolate } \\
\text { character } \\
\text { based on } \\
\text { gram } \\
\text { staining }\end{array}$ \\
\hline TR-15.1 & 8 & $3.41 \pm 0.48$ & 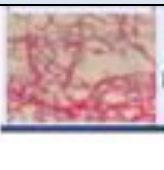 & $\begin{array}{l}\text { Long-chain } \\
\text { Bacili, } \\
\text { Gram- } \\
\text { negative } \\
\text { bacteria }\end{array}$ \\
\hline
\end{tabular}

\subsection{Production and Proteolytic Activity of Crude Proteases}

The selected TR-4.1, TR-10, and TR-15.1 isolates were grown in production media containing peptone as a nitrogen source. The activity of the crude proteases was determined using casein as the substrate. The findings of this study are summarized in Table 3. Despite growing in a peptone-rich medium, the results showed that the TR-4.1 isolate did produce an adequate amount of protease to hydrolyze casein hydrolysis. In contrast, the TR-10 and TR-15.1 isolates produced proteases that hydrolyzed casein at variable proteolytic rates. The protease activity of the TR-15.1 isolate (1.07 $\pm 0.14 \mathrm{U} / \mathrm{mL})$ was greater than the TR-10 isolate (0.22 $\pm 0.05 \mathrm{U} / \mathrm{mL})$ (Table 3). Some literature indicates that peptone is an available nitrogen source to induce protease production [11, $24,29]$. The reason for the TR-4.1 isolate not showing protease activity despite the high proteolytic index, thus had likely to do with the extensive production time (72 hours) used in this study. Presumably, under these conditions, the TR-4.1 isolate had reached the death phase (no protease activity), while other isolates were in the exponential phase and producing the proteases.

Table 3 Protease Activity of TR-4.1, TR-10, and TR-15.1 Isolates

\begin{tabular}{ll}
\hline Isolate & Protease Activity $(\mathbf{U} / \mathbf{m L})$ \\
\hline TR-4.1 & 0 \\
TR-10 & $0.22 \pm 0.05$ \\
TR 15.1 & $1.07 \pm 0.14$ \\
\hline
\end{tabular}

Literature has shown that different bacterial species exhibit varying metabolic pathways and properties in response to their surrounding environment [24, 29]. The different pathways invariably result in different kinds of metabolites, such as proteases of varying proteolysis rates. Hence, the outcome seen here also affirmed that the TR-4.1, TR10, and TR-15.1 isolate were likely from different bacterial species, supporting the earlier observed differences in their colony and cell morphologies. 
3.3 Protease Activity and Pathogenicity assay of Bacterial Isolates as Candidate Protease for Extraction of Collagen from Milkfish Scales

It is pertinent to indicate here that the ability of the crude proteases to extract collagen from scales of milkfish was gauged from the increase in protein content, known as collagen solubilizing protease, in the reaction mixture after the enzymatic treatment $[6,7,8]$. The results of the study are shown in Figure 1. As can be seen, the increase in the total protein of the mixture experienced by TR-10 and TR-15.1 isolates proved that the bacterial proteases were effective in hydrolyzing the peptide bonds of connective tissue on the scales of milkfish. The enzymes' action liberated more of the locked protein from the fish scales, increasing collagen yield in the reaction mixture. The outcome seen here affirmed that the TR10 and TR-15.1 protease were promising candidates for the enzyme-assisted extraction of collagen from milkfish scales. Crucially, their use in this process could support a more sustainable approach to harvesting valuable collagen from milkfish waste.

Meanwhile, the TR-4.1 isolate produced a negative value of total soluble protein $(-25,39 \pm 1,12$ $\mu \mathrm{g})$ compared to $179.9 \pm 1.15 \mu \mathrm{g}$ for TR-10 and $19,14 \pm 2,66 \mu \mathrm{g}$ for TR-15.1. This meant that the total protein in mixture A (Crude extract of protease + milky fish scales) of the TR-4.1.1 experiment was lower than mixture $\mathrm{B}$ (crude extract of protease). The negative value seen here for the TR-4.1 experiment is presumptive that the lower soluble protein in mixture A was due to adsorption of the enzymaticallyliberated protein onto the fish scales. However, mixture $C$ (which is the negative control) showed that the protein content remained constant throughout the whole process. This proved that the water-soluble protein was not absent before the enzymatic treatment on the milkfish scales. In line with this, the seemingly reduced total protein in mixture $A$ in the TR-4.1 experiment indicated a stagnant total protein content. It can be construed that the protease produced by the TR-4.1 isolate in peptone-rich media containing was unusable for extracting collagen from milkfish scales. To prove that the liberated protein (increase in the total of protein) was collagen, further research using SDS-PAGE on the three mixtures (A, B, and C) may prove useful $[7,21]$.

The absence of soluble protein in the negative control reaction (mixture $C$ ) in the TR-4.1 experiment corroborates the newly produced water-soluble proteins (from collagen production) brought about by the actions of the TR-15.1 and TR-4.1 proteases on the milky fish scales. The leaching of fish scales was probably due to unclean fish scales, or the samples had naturally degraded before the enzymatic treatment. The two above outcomes were possible as the milkfish samples were a few days old upon collection. By then, natural proteolysis by other microorganisms present on the fish scales would have taken effect.
The protease activity produced by TR-10 and TR15.1 isolates was inversely related to its ability to extract the collagen of milkfish scales (Table 3 and Table 4). Interestingly, despite the lower protease activity of TR-10 compared to TR-15.1, the former was more efficient in extracting collagen from milkfish scales. This was evident from the appreciably increased soluble protein content in the TR-10 experiment, which came from hydrolyzed peptide bonds in the connective tissue of the fish scales. Also, the outcome inferred that the TR-10 crude protease was less specific towards casein as the substrate, hence was an unsuitable substrate for estimating the protease activity of the TR-10 crude enzyme. Based on the cumulative findings, it can be interpreted that the TR-10 bacterial isolate from the Sidoarjo shrimp paste is a promising producer of halal protease for collagen extraction from milkfish scales. Moreover, the bacterial protease could promote a more sustainable collagen-harvesting process from other types of fish scales, too. However, it is only an assumption, and the feasibility of this protease for such a purpose remains to be seen.

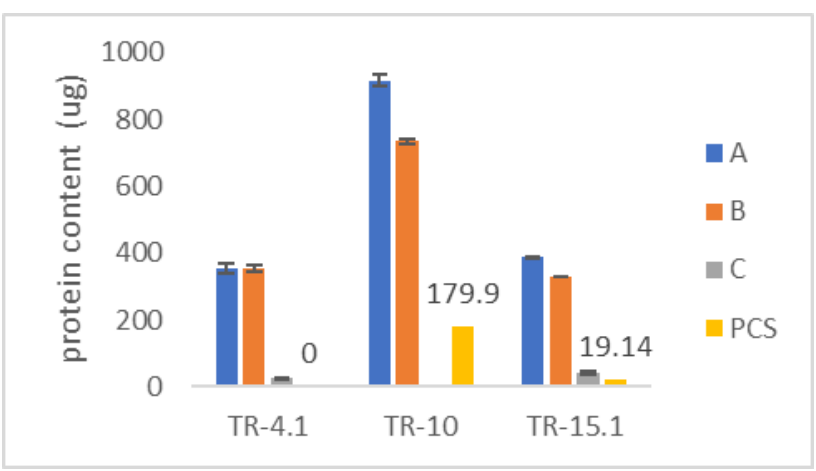

Figure 1 Protein content of crude extract of protease + milky fish scales (A), crude extract of protease (B), distilled water + milky fish scales $(\mathrm{C})$, and the collagen solubilizing protease from milkfish scales by crude proteases (PCS) from the bacterial isolate of TR-4.1, TR-10, and TR-15.1

3.4 Pathogenesis Test and Molecular Identification of TR-10 Bacterial Isolate

Since only the TR-10 bacterial was adept at extracting collagen from milkfish scale, the isolate was tested by pathogenesis test and the bacterial sequence was extracted and subjected to further molecular analysis. Pathogenesis test results showed that TR-10 isolate did not form a clear zone around its colonies growing on blood agar media (Figure 2), indicating that the TR-10 isolate was nonpathogenic. 


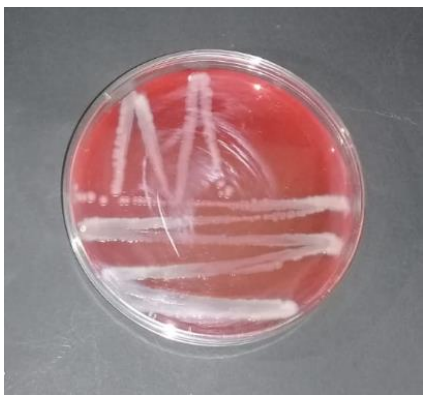

Figure 2 Pathogenesis test of TR-10 isolate

The Basic Local Alignment Search Tool (BLAST) result shows that the TR-10 isolate showed homology to Bacillus megaterium ML482 (Table 4) and is located in one cluster as shown at the phylogenetic tree in Figure 3. Interestingly, the B. megaterium ML482 was previously explored for its ability to produce specialized enzymes that solubilize inorganic phosphates [26]. The bacterium has yet to be investigated for protease production. Thus, this indicated that there is much unknown about this bacterium and the different enzymes that it produces. The Bacillus flexus family is known to be a halophile, has good tolerance in an environment with high salinity and has the potential to degrade biomass waste $[27,28]$.

Table 4 The percentage of similarity between isolates

\begin{tabular}{|c|c|c|}
\hline Isolate & Similar isolates & $\begin{array}{l}\text { percentage of } \\
\text { similarity (\%) }\end{array}$ \\
\hline \multirow[t]{15}{*}{ TR-10 } & Bacillus megaterium ML482 & 100 \\
\hline & Bacillus megaterium IAM 13418 & 99,69 \\
\hline & Bacillus flexus IFO15715 & 98.99 \\
\hline & Bacillus acidiceler CBD 119 & 94.71 \\
\hline & Bacillus luciferensis LMG 18422 & 94.62 \\
\hline & Bacillus anthracis ATCC 14578 & 94,52 \\
\hline & Bacillus mycoides ATCC 6462 & 94,44 \\
\hline & Bacillus cereus ATCC 14579' & 94,44 \\
\hline & Bacillus cereus K54 & 94,44 \\
\hline & $\begin{array}{l}\text { Bacillus thuringiensis ATCC } \\
10792^{\top}\end{array}$ & 94,36 \\
\hline & Bacillus velezensis BCRC 17467' & 93,52 \\
\hline & Bacillus pseudofirmus DSM 8715 & 93,43 \\
\hline & Bacillus amyloliquefaciens & 93.27 \\
\hline & NBRC $15535^{\top}$ & \\
\hline & Klebsiella pneumoniae 1.3 & 71.74 \\
\hline
\end{tabular}

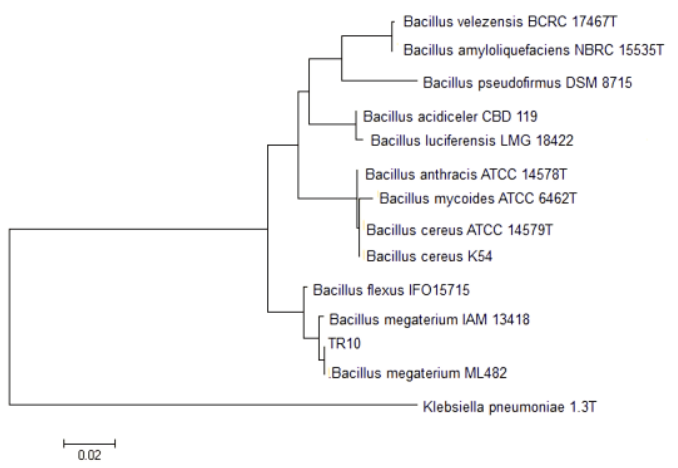

Figure 3 The phylogenic tree of the 16S rRNA of the TR-10 isolate sequence obtained for the $B$. megaterium species

\subsection{CONCLUSION}

This study successfully isolated a total of 19 proteaseproducing isolates from the Sidoarjo shrimp paste. Isolates TR-4.1, TR-10, and TR-15.1 were found to show promising use as proteases in extracting collagen from milkfish scales. Only the TR-10 crude protease was suitable to extract the collagen from milkfish scales. The 16S rRNA analysis showed the TR-10 bacterium shares $100 \%$ homology with the Bacillus megaterium ML482, previously reported as a microbial agent for solubilizing inorganic phosphates. Supported by the non-pathogenicity of the TR-10 bacterium, further studies into optimizing the mass production of its crude protease may prove useful to enhance the enzyme-assisted extraction of collagen from milkfish scales.

\section{Acknowledgement}

On this occasion, the author would like to thank to Lembaga Penelitian dan Pengabdian Masyarakat Universitas Negeri Malang (LP2M UM) by funding this research on PNBP 2020. Addition, we thank you to our colaborating students are Muhammad Roy Asrori and Imanda Nurul Setia .

\section{References}

[1] Schmidt, M. M., Dornelles, R. C. P., Mello, R. O., Kubota, E. H, Mazutti, M. A., Kempka, A. P., I. M. 2016. Collagen Extraction Process. International Food Research J. 3: 91322.

[2] Iwanah, F. 2012. Pengaruh Penggunaan Limbah Ikan Bandeng (Chanos chanos Forsk) dalam Ransum sebagai Substitusi Tepung Ikan terhadap Konsumsi Pakan, Pertambahan Bobot Badan dan Konversi Pakan Ayam Pendaging. Skripsi. Universitas Islam Negeri (UIN) Malik Ibrahim; Malang.

[3] Yang, Hua, Shu, Z. 2014. The Extraction of Collagen Protein from Pigskin. $J$ of Chemical and Pharmaceutical Research. 2: 683-87.

[4] Thuy, M., Thi, L., Okazaki, E., Osako, K. 2014. Isolation and Characterization of Acid-soluble Collagen from the Scales of Marine Fishes from Japan and Vietnam. Food Chem. 149: 267-70.

[5] Singh, Prabjeet, Benjakul, S., Maqsood, S., Kishimura, H. 2011. Isolation and Characterization of Collagen Extracted from the Skin of Striped Catfish (Pangasianodon hypophthalmus). Food Chem. 1: 97-105.

[6] Kittiphattanabawon, Phanat, Benjakul, S., Visessanguan, W., Shahidi, F. 2010. Isolation and Characterization of Collagen from the Cartilages of Brown-banded Bamboo Shark (Chilosyllium punctatum). LWT-Food Scie and Tech. 5: 792-800.

[7] Mahboob, S., Haider, S., Sultana, S., Al Ghanim, K. A., Ahmad, Z. 2014. Isolation and Characterization of Collagen from Waste Material of Two Important Freshwater Fish Species. The J. of Animal \& Plant Scie. 6.

[8] Kittiphattanabawon, Phanat, Benjakul, S., Sinthusamran, S., Kishimura, H. 2015. Characteristics of Collagen from the Skin of Clown Featherback (Chitala ornata). Int J. of Food Scie \& Tech. 9: 1972-78.

[9] Badan Pusat Statistik Kabupaten Sidoarjo. 2016. Statistik Daerah Kabupaten Sidoarjo, (Online), 
(https://www.scribd.com/document/327540037/StatistikDaerah-Kabupaten-Sidoarjo-2016.

[10] Song, Wei. 2014. Extraction Optimization and Characterization of Collagen from the Lung of Soft-shelled Turtle Pelodiscus Sinesis. Int. J. of Nutrition and Food Scie. 4: 70

[11] Alnahdi, Hanan. 2012. Isolation and Screening of Extracellular Proteases Produced by New Isolated Bacillus sp. J. of Applied Pharm. 9: 71-74.

[12] Chantawannakul, Panuwan, Onchatoen, A., Klanbut, K., Chukeatirote, E., Lumyong, S. 2002. Characterization of Proteases of Bacillus subtilis-38 Isolated from Traditionally Fermented Soybean in Northern Thailand. Science Asia. 28: 242-45.

[13] Cho, S. J., Oh, S. H., Pridmore, R. D., Juillerat, M. A., Lee, C. H. 2003. Purification and Characterization of Proteases from Bacillus amyloliquefaciens Isolated from Traditional Soybean Fermentation Starter. J. of Agri. and Food Chem. 51 (26): 7664-7670.

[14] Susanti, E., Suharti, Ramadhan, H. R., Fatma, F. 2017. Isolasi dan Seleksi Bakteri Proteolitik dari Tauco Pasar Besar Malang. Seminar Nasional Kimia dan Pembelajarannya (SNKP). Malang: Department Chemistry Universitas Negeri Malang. 172-82.

[15] Novi, A. 2015. Isolasi dan Identifikasi Bakteri Penghasil Protease yang Diskrining dari Terasi. El- Hayah. 3: 119-22.

[16] Bollag DM, Rozycki MD, Edelstein SI (1996) Protein Methods 2nd Ed. New York John Wiley and Sons.

[17] Lowry, O. H., Rosebrough, N. J., Farr, A. L., \& Randall, R. J. 1951. Protein Measurement with the Folin Phenol Reagent. Journal of Biological Chemistry. 193: 265-275.

[18] Chusniyah, Naharotul. 2016. Isolasi Bakteri Penghasil Protease dari Terasi Sidoarjo untuk Isolasi Kolagen dari Sisik Ikan Bandeng. Skripsi tidak diterbitkan. Malang: FMIPA UM.

[19] Hawaz, Estifanos. 2014. Isolation and Identification of Probiotic Lactic Acid Bacteria Curd and in Vitro Evaluation of Its Growth Inhibition Activities Against Pathogenic Bacteria. African J. of Micro Research. 8(13): 1419-25.

[20] Tamura, K., Nei, M. and Kumar, S. 2004. Prospects for Inferring Very Large Phylogenies by using the Neighbor-
Joining Method. Proceedings of the National Academy of Sciences of the United States of America. 101: 1103011035.

[21] Soeka, Yati S., Sulistiani. 2014. Karakterisasi Protease Bacillus subtilis Al InaCC B398 (Characterization of Protease Bacillus subtilis Al InaCC B398 Isolated from Shrimp Paste Samarinda). Berita Biologi. 13: 203-12.

[22] Akhdiya, A. 2003. Isolasi Bakteri Penghasil Enzim Protease Alkalin Termostabil. Buletin Plasma Nutfah. 2: 38-44.

[23] Nagai, Takeshi, Tanove, Y., Kai, N., Suzuki, N. 2015. Characterization of Collagen from Emu (Dromaius novaehollandiae) Skin. J. of Food Scie and Tech. 4: 234451.

[24] Monika, R., Evi, S. 2017. Optimasi Jenis dan Kadar Sumber Nitrogen serta $\mathrm{pH}$ Medium untuk Produksi Protease dari Isolat HTCUM6.2.2 dari Tauco Surabaya. Jurnal Kimia Riset. 2(2): 98-107.

[25] Anggo, Dwi A., Swastawati, F., Rianingsih, L. 2014. Mutu Organoleptik dan Kimiawi Terasi Udang Rebon dengan kadar Garam Berbeda dan Lama Fermentasi. JPHPI. 17 53-59.

[26] Zheng, B. X., Ibrahim, M., Zhang, D. P., Bi, Q. F., Li, H. Z., Zhou, G. W., Ding, K., Peñuelas, J., Zhu, Y. G. and Yang, X. R. 2018. Identification and Characterization of InorganicPhosphate-solubilizing Bacteria from Agricultural Fields with a Rapid Isolation Method. AMB Express. 8(1): 1-12.

[27] Shankar, N. Panchapakesan, A. Bhandari, S. and Ravishankar, H. N. 2014. Simultaneous Cellulose Hydrolysis and Bio-electricity Generation in a Mediatorless Microbial Fuel Cell using a Bacillus Flexus Strain Isolated from Wastewater. Research in Biotechnology. 5(1).

[28] Trivedi, N., Gupta, V., Kumar, M., Kumari, P., Reddy, C. R. K. and Jha, B. 2011. An Alkali-halotolerant Cellulase from Bacillus Flexus Isolated from Green Seaweed Ulva Lactuca. Carbohydrate Polymers. 83(2): 891-897.

[29] Rajkumar, R., Jayappriyan, K. R., Kannan, P. R. and Rengasamy, R. 2010. Optimization of Culture Conditions for the Production of Protease from Bacillus Megaterium. Journal of Ecobiotechnology. 2(4). 